Vol. 9, n² | 2005

Varia

\title{
Martin J. Wiener, Men of Blood: Violence, Manliness and Criminal Justice in Victorian England
}

Cambridge: Cambridge University Press, xiv + 296 pp., ISBN 0521831989 (hardback)

Louise A. Jackson

\section{(2) OpenEdition Journals}

Electronic version

URL: https://journals.openedition.org/chs/299

DOI: $10.4000 /$ chs. 299

ISSN: 1663-4837

\section{Publisher}

Librairie Droz

\section{Printed version}

Date of publication: 1 December 2005

Number of pages: 125-128

ISBN: 978-2-600-01054-2

ISSN: 1422-0857

\section{Electronic reference}

Louise A. Jackson, "Martin J. Wiener, Men of Blood: Violence, Manliness and Criminal Justice in Victorian England", Crime, Histoire \& Sociétés / Crime, History \& Societies [Online], Vol. 9, n² | 2005, Online since 11 February 2009, connection on 23 March 2022. URL: http://journals.openedition.org/chs/299 ; DOI: https://doi.org/10.4000/chs.299

This text was automatically generated on 23 March 2022.

(C) Droz 


\section{Martin J. Wiener, Men of Blood: Violence, Manliness and Criminal Justice in Victorian England}

Cambridge: Cambridge University Press, xiv + 296 pp., ISBN 0521831989 (hardback)

Louise A. Jackson

\section{REFERENCES}

Martin J. Wiener, Men of Blood: Violence, Manliness and Criminal Justice in Victorian England, Cambridge: Cambridge University Press, xiv + 296 pp., ISBN 0521831989 (hardback).

Whilst the study of Victorian masculinity has highlighted attempts to replace libertinism and pugilism with chivalric and heroic models, its significance for criminal justice history is only just beginning to be felt in published work. Historians of sexuality, such as Ed Cohen and Angus McClaren, have shown that the spectacle of the criminal trial constituted one arena in which normative heterosexual masculinities were contested, debated and reinforced in the late nineteenth century ${ }^{1}$. Many standard textbooks, however, tend to discuss the gendering of criminality by focusing overwhelmingly on women. Martin Wiener's impressive work, Men of Blood, is to be welcomed not only because it fills a huge gap in the field by demonstrating how changes in ideas about manliness affected decision-making at the highest levels of Victorian justice, but also because of the scope and depth of its scholarship, which sheds considerable light on the relationship between civil servants, judges, juries and the wider public. Most significantly, he argues very convincingly that we need to think of Victorian criminal justice as a contested but shifting terrain, in which concerns about liberal citizenship ultimately created a very different approach to gender and justice than that which had been adopted in the eighteenth century. A key characteristic of nineteenth-century England was a concern about violence: within a 
hierarchy of crime and punishment, offences against the person were increasingly dealt with as more serious than crimes against property. Murders became more publicly visible within newspaper coverage and drunken brawls were much more likely to go to court. Given that cases involving violence tended to involve male protagonists, masculinity itself was a key target of the judicial process.

2 Wiener has assembled a data sample of 'several thousand' ( $p$. xiii) homicide and rape trials that took place in assize courts across the century and which were reported in The Times and The Central Criminal Court Sessions Papers (Old Bailey). In addition to providing a quantitative and qualitative analysis of their outcomes, he assesses changes in statute and case law as well as in the appeal process, plotting a clear trend across time. Wiener's thesis is that 'men's violence, particularly against women... was viewed with ever-greater disapproval and treated with ever-greater severity' (p. xii). Emerging feminist voices, prominent in campaigns around wife-beating and women's legal/ political rights, united with a paternalist concern for order, sensibility and respectability that increased as the working class was enfranchised. Aggression - even when exhibited in defence of 'honour' - was gradually perceived not only as 'unmanly' but also as 'un-English' within the context of imperialism and citizenship. This chivalric and stoical model was increasingly promoted by the Home office, assize judges and, to a lesser extent, amongst juries. Other competing models of masculinity continued within public opinion; the 'civilising mission' was negotiated and contested as decisions were discussed and debated within the criminal justice system. The net effect, however, was a 'reconstruction' of 'male ideals' and 'to a lesser but nonetheless significant extent, of male behaviour' (p. 6). Wiener makes the important point that the chivalric desire to protect women and children created 'the conditions for real change in social relations' and significantly altered lives for the better.

Men of Blood offers a detailed discussion of attempts to punish both dueling and fistfights between men more severely, suggesting this was not simply a middle-class clamp-down on working-class behaviours. However, the majority of the book deals with men's violence against women, firstly through an examination of sexual violence, which focuses on rape charges. Wiener convincingly demonstrates that rape was redefined during the Victorian period. Firstly, it was viewed as an offence against a woman - as a person in her own right - rather than as the property of her husband. Secondly, proof of emission and the rupture of the hymen were no longer necessary for a conviction. Finally, the amount of force that women were expected to exert by way of resistance diminished as Victorian ideologies positioned women as passive by nature. Even women who did not conform to conceptions of feminine modesty were surprisingly able, on occasion, to bring successful convictions for rape. Assisted by the abolition of the death penalty for rape in 1841 , there were increases in the number of rape trials as well as the percentage of trials leading to conviction (convictions rose from $10 \%$ in the late 1830 s to an estimated $60 \%$ in the second half of the century).

4 Whilst Wiener alludes to substantial datasets, one of the weaknesses in his discussion of rape is the lack of comprehensive statistical tables to profile results. Data aggregates, instead, are buried in the footnotes and, somewhat confusingly, quantitative conclusions are drawn from the studies of other researchers as much as from primary sampled material. In order to demonstrate the efficiency of the Victorian criminal justice system, Wiener compares the late-nineteenth-century estimate of $60 \%$ with latetwentieth-century rape conviction rates of $24 \%$ in 1985 and $9 \%$ in 1997 . Yet he omits to 
indicate that these refer to all officially reported cases rather than cases that went to trial (p. 87, n. 48). Indeed, it remains unclear what proportion of Victorian rape allegations were actually tried since the data is not laid out explicitly. Wiener concedes that 'magistrates tended to be more lenient to accused rapists than High Court judges' (p. 117, n. 151). Yet he does not mention that magistrates - as the gatekeepers of the criminal justice system - exercised considerable discretion at the committal stage in deciding whether there was a case to answer. They might also deal with similar offences on lesser assault charges. There was clearly some increase in prosecutions, particularly in complainants under the age of consent. However, it could be argued that the increase in prosecutions by adult women was marginal. The claim that transformations in the treatment of rape within the criminal justice system meant that 'men were no longer practically at their liberty to take their pleasure with women whose reputation was dubious...' needs to be heavily qualified (p. 109). The shift was there but it was subtle and complex rather than seismic.

Wiener's fascinating discussion of the gendering of homicide trials is based on a very careful and detailed profiling of sample cases. Most significantly, he reveals that, across the nineteenth century, an increasingly large proportion of all murder trials $-30 \%$ by the 1890s - involved the murder of wives by husbands. This was not paralleled by a similar national increase in cases involving the murder of husbands by wives, which remained constant at approximately one a year. The explanation for this surprising trend is demonstrated to lie in legal changes rather than any actual increase in violence against women. Wife killings that had appeared previously as manslaughter were increasingly being tried as murder. The notion of 'intent' was recast to refer to the moment of action rather than lengthy premeditation; the use of a lethal weapon was no longer considered essential for murder. There were also ideological transformations as 'new cultural discourses of gender, morality and violence' depicted the drunken brutish husband as a social problem in need of control (p. 154). This meant that, by the 1870s, a man who 'kicked his wife to death' was likely to be tried for murder rather than manslaughter. Furthermore, men's arguments about provocation were less likely to lead to a mitigated sentence or a lesser charge. Women's verbal insults were less likely to exculpate men as 'the shrew' lost her power (p. 177). Even a wife's drunkenness, despite its contradiction of domestic ideology, was increasingly unlikely to evince the sympathy of judges and many jurors. Women's infidelity created conflict between judges, jurors and the Home office as cuckolds 'changed from figures of malicious humour into figures of tragedy'(p. 204). Yet, on balance, there was 'diminished tolerance for the killing of even an unfaithful wife' (p. 205).

6 Wiener recognises that murder cases were 'atypical' precisely because they ended in fatality, but views them in terms of a 'continuum of marital violence' (p. 146, n. 81). Yet they were also atypical in that they were dealt with by judges and juries rather than magistrates, as well as in the publicity they generated (because of their infrequency). It could be argued, therefore, that homicide cases were treated with exemplary care because they were unusual. Whilst Wiener's arguments about the assize and appeal process are meticulously made, it remains to be demonstrated to what extent the attempt to reconfigure masculinity as pacific was followed through at the level of petty sessions, where magistrates dealt with everyday violence on a routine basis.

7 Throughout Men of Blood, one of Wiener's central targets for criticism is a feminist approach to gendered violence that has sought to 'flatten' the past by invoking an 
ahistorical model of 'patriarchy' as an explanatory framework. To some extent it is a 'straw woman' version of feminist scholarship that is suggested. The utility of the term 'patriarchy' has been extensively debated by historians of women. Recent 'feminist' scholarship on gender and justice has sought to examine the ways in which gender ideologies were constantly in flux during the course of the nineteenth century. Writing in 1992, for example, Judith Walkowitz sought to question 'old fashioned assumptions about a centralized and stable hierarchy of power'. In her analysis of working women's experiences of violence, published in 1998, Shani D'Cruze argued that the dynamics of Victorian gender relations were 'too complex to admit any over-simplified interpretation of male conspiracy's. Wiener prefers to argue that patriarchy was being dismantled step by step during the course of the nineteenth century as women gained civil and political rights (p. 162). One of the problems, however, with this alternative grand narrative is its adherence to a whiggish formula that, effectively, positions the nineteenth century as part of a march of progress, which culminates in votes for all adult women in 1928. Such a perspective fits uncomfortably with the historicist approach that is invoked elsewhere in the text as an ideal.

Wiener's concept of 'gender' also differs from that of feminist historians in that, like the term 'violence' itself, he sees it as a 'social' concept 'grounded in nature' (p. 9). Within feminist scholarship, the recent tendency has been to use 'gender' to denote the cultural and historical construction of masculinity and femininity as performed roles and, indeed, to critique the ways in which biological science has equated women with 'nature'. Wiener prefers to view gender as mutually constituted by both the cultural and the biological. Whilst creating a 'cultural history' of violence, he clearly acknowledges the significance of physicality, force and strength, which is clearly an admirable, worthy and important endeavour. This does, nevertheless, create tensions that are difficult to resolve. References to the work of evolutionary psychologists and anthropologists on the prevalence of male violence in all societies could be seen to reinforce the types of essentialism (including certain radical feminist accounts of patriarchy) that Wiener rejects elsewhere.

9 Although its central thesis is over-stated given its concentration on assize courts only, Men of Blood is undoubtedly an extremely important work, which will stimulate considerable debate and attention. It is highly relevant to all scholars and students of gender, crime and the Victorian social order; any review cannot do justice to the richness and complexity of information that is contained within its 300 pages. Further detailed work on petty sessions hearings will enable historians to demonstrate whether, indeed, men's violence was 'treated with ever greater severity' across the criminal justice system. Those working on the twentieth century will also be keen to examine further the apparent easing off of 'the civilising offensive' after 1900. Like all significant works Men of Blood has set the ball rolling by raising important questions that can only be resolved through future research. 


\section{NOTES}

1. Cohen E. (1993) Talk on the Wilde Side. Towards a Genealogy of a Discourse on Male Sexualities. London, Routledge; McLaren A. (1997) The Trials of Masculinity. Policing Sexual Boundaries, 1870-1930. Chicago, University of Chicago Press.

2. Walkowitz J. (1992) City of Dreadful Delight. Narratives of Sexual Danger in Late-Victorian London, London, Virago, p. 9.

3. D'Cruze S. (1998) Crimes of Outrage. Sex, Violence and Victorian Working Women, London, UCL Press, p. 172.

\section{AUTHORS}

\section{LOUISE A. JACKSON}

(Leeds Metropolitan University), 1.jackson@leedsmet.ac.uk 